DOI: https://doi.org/10.32839/2304-5809/2021-5-93-23

УДК 343.614

Маслова 0.O.

Національний юридичний університет імені Ярослава Мудрого

Кунченко А.A.

Інститут прокуратури та кримінальної юстиції

Національного юридичного університету імені Ярослава Мудрого

\title{
АНАЛІЗ ПРАВОПОРУШЕННЯ ДОВЕДЕННЯ ДО САМОГУБСТВА
}

Анотація. У статті представлено комплексне дослідження кримінально-правових характеристик складу правопорушення, передбаченого статтею 120 Кримінального кодексу України - доведення до самогубства або до замаху на самогубство. Вивчаються окремі аспекти вчинення цього правопорушення, його головні ознаки та найбільш визначальні риси. Запропоновані висновки щодо розуміння понять самогубства як акту самокалічення або самоліквілації, а також інших понять, таких як доведення до самогубства та схиляння до самогубства, спосіб доведення до самогубства, зазначені й інші дії, що сприяють доведенню людей до самогубства. Розглянуто деякі дискусійні питання щодо суб'єктивної сторони складу даного правопорушення та додано позиції видатних вітчизняних вчених стосовно їх бачення проблематики доведення особи до самогубства. Наводиться нова редакція ст. 120 КК Украіни від 8 лютого 2018 року в аспекті розширення переліку способів вчинення досліджуваного протиправного діяння. Запропоновані дані щодо динаміки вчинення правопорушення на даний момент в Україні і світі в цілому та чинники, що провокують вчинення правопорушення. Розглянуто доведення та схиляння до самогубства найбільш психологічно незахищених верст населення - підлітків та малолітніх осіб різноманітними онлайн-спільнотами, іграми та безпосередньо їхніми членами сім'ї шляхом насильства чи прямого булінгу. Запропоновано способи удосконалення вітчизняного законодавства в аспекті врегулювання даного правопорушення в умовах сучасності та активного розвитку технологій для найефективнішого застосування кримінального законодавства, боротьби з проблемою та зведення до мінімуму виникнення випадків доведення інших осіб до самогубства. В статті також присутній короткий аналіз кримінальних кодексів зарубіжних країн, таких як Росія, Республіка Молдова, Данія, Айзербайджан, Сан-Маріно та інших в частині доведення до самогубства, замаху на самогубства, схиляння, допомоги вчинення самогубства, тощо. Також проаналізовано історичний досвід розвитку законодавчого врегулювання даного протиправного діяння в УСРР, правонаступницею якої є наша держава.

Ключові слова: правопорушення, доведення до самогубства, замах на самогубство, кваліфікуючі ознаки, схиляння до самогубства, сприяння, спосіб вчинення, суб’ективна сторона

\section{Maslova Olena \\ Yaroslav Mudryi National Law University \\ Kunchenko Anna \\ Institute of Prosecutor's Office and Criminal Justice \\ Yaroslav Mudryi National Law University}

\section{ANALYSIS OF THE OFFENCE OF LEADING TO SUICIDE}

Summary. The article presents a comprehensive view of criminal law composition of the offence that is provided by the article 120 of the Criminal codex of Ukraine - driving to suicide or to an arrempt of suicide. Some aspects of the offence commiting are studied as well as its main characteristics and the most significant features. There are some conclusions to understanding such terms as suicide, for example, which is seen as an act of self-destruction or self-harm are offered. Also, other terms like driving to the suicide, suicidal tendencies, promotion, method of commision and other actions which help driving other people to the suicide are viewed. Some debatable issues like a subjective side of the composition of the offence are studied and notions of outstanding ukranian scientists concerning their point of view on the problem of bringing individuals to the suicide are also presented in the article. The new version of the art.120 of the criminal codex of Ukraine from the 8th of February 2018 is here listed to show the expanding transformation of the ways of commiting this particular offence. The fresh data on the dynamic of commiting the offence in modern Ukraine and whole world in general is accommodated and triggers that lead to commiting this offence are pointed on. Leading the most psychologically vulnerable segments of population which are children and very young people, adults in general to the suicide in different ways by using suicidal online-communities and games is also payed attention to. Other ways of bringing young people to suicide are considered to be family abuse and direct bullying or violence from other people. The methods of improving the current legislation in the aspect of regulating the current law-enforcment of this offence in the situation of the current active development of technologies for the most effective application of norms of the criminal law and fighting the problem of suicides occuribg due to other people`s influence as well as minimizing the cases of such an offence and its effects have been proposed. The article also contains a short analysis of the criminal codes of foreign countries, such as Russia, the Republic of Moldova, Daniya, Azerbaijan, San-Marino, and others in part of bringing to suicide, swinging at suicide, scheming, supplementary committing suicide. It has also analyzed the historical information about the development of the legislative regulation of this felonious act in the USRR, since Ukraine is considered to be its successor.

Keywords: offence, leading to suicide, attempt of suicide, qualifying attributes, suicidal tendencies, promotion, method of commision, subjective side. 
Постановка проблеми. Життя людини-найвища соціальна цінність. Норми кримінального права покликані забезпечити ї̈ охорону. Одна з них спрямована на безпосередній захист від вчинення самогубства під впливом сторонніх осіб - стаття 120 Кримінального кодексу. Суспільна небезпека цього злочину характеризуеться не тільки тим, що він посягає на природне невід'ємне право людини, але і цинізмом, жорстокістю, аморальністю і спрямованістю проти гуманістичних засад у взаєминах людей. Звернула увагу на проблему і Всесвітня організація охорони здоров'я (ВООЗ), вона визнала їі небезпеку для суспільного здоров'я і опублікувала стратегію щодо підвищення усвідомлення їі масштабів владою та суспільством $[1$, с. 13]. Варто зазначити, що і в Україні самогубства не рідке явище: наша країна входить у десятку за найвищим рівнем самогубств: лише за 2017 р. зафіксовано 15000 актів суїциду. За багатьма фрактами самогубств яскраво простежуеться кримінальна складова. Безліч жертв суїциду штовхаються свідомо на це діяння іншими людьми. Незважаючи на збільшення числа самогубств, кримінальні справи за ст 120 КК практично відсутні: з 2010 р. по 2017 р. винесено тільки 5 вироків, і лише 4 з них набрали законної сили, тобто фрактично маємо менше 1 такого вироку на рік. Проте це зовсім не означае не, що всі люди вчиняють самогубства з власної волі, не зазнаючи жодного тиску ззовні. Справжнім поясненням відсутності таких кримінальних справ $є$ важкість розслідування подібного роду правопорушень. Часто слідчі не можуть дійти висновку що самогубство було вчинено під впливом іншої людини - бракуе свідків, доказів, тощо. Також варто зазначити, що з розвитком людства, появою соціальних мереж з'явився і кібербулінг та онлайн-спільноти самогубц, що обумовило внесення змін у статтю 120 КК України з метою притягнення до відповідальності за доведення до самогубства не тільки прямим фізичним впливом, a і психологічнимшляхом схиляння. Та не варто забувати і про самогубства, вчинені неповнолітніми на грунті зневажливого ставлення до них з боку інших членів їхньої сім'ї, самогубства, вчинені через насильство в сім'ї, через матеріальну, службову, іншу залежність, булінг в школі та інших закладах навчання, на роботі. Причин багато, і вони заслуговують на увагу.

Стан дослідження. Проблему доведення до самогубства досліджували такі вчені, як Л.М. Шестопалова, О.А. Гусак, О.О. Колінько, С.В. Бородіна, Є.Л. Стрельцова, В.О. Тулякова, О.Р. Цой, Ю.О. Уколова, А.П. Чупрікова.

Невирішені раніше частини загальної проблеми. Невстановленість чіткої субективної сторони, необхідність ї̈ доповнення корисливим мотивом як кваліфрікуючою ознакою вчинення даного правопорушення. Окрім цього, відсутня можливість звільнення від кримінальної відповідальності за правопорушення у разі відмови від вчинення винним дій, спрямованих на доведення до самогубства, а також за наявності певних дій щодо подолання негативних наслідків діяння

Метою цієї статті є дослідження понять доведення до самогубства, схиляння, фрізичного впливу, дослідження складу даного правопору- шення, способів його вчинення, аналіз історичної еволюції врегулювання правопорушення та кримінальних законодавств інших країн в розрізі доведення до самогубства.

Виклад основного матеріалу. Доведення особи до самогубства є поширеним явищем та викликає стурбованість, оскільки становить загрозу для моральних засад соціуму, посягає на життя людини. Залучення громадськості у вирішення даного питання та програм з боротьби з насильством у сім'ї, профрілактика самогубств є дієвими методами у боротьбі з проблемою.

Згідно статті 3 Конституції України, людина, iï життя, здоров'я, честь і гідність, недоторканість і безпека є найвищою соціальною цінністю. Стаття 2 Конвенції про захист прав людини та основоположних свобод та стаття 6 Міжнародного пакту про громадянські і політичні права також проголошують, що право на життя - під охороною закону. Безліч інших міжнародних актів стоять на таких же позиціях, що зумовлюе наявність у вітчизняному кримінальному законі норм, спрямованих на охорону життя. В умовах Євроінтеграції таке доповнення законодавства абсолютно актуальне.

Попри вознесення цінності життя, кожні 40 секунд у світі трапляеться самогубство, причиною чого $е$ i негативний вплив з боку інших людей. Країнами-лідерами за числом самогубств є Японія, Литва, Росія, Угрощина, Україна та ряд інших. Серед потерпілих велика кількість неповнолітніх та молоді, що аж ніяк не покращуе становище. Доведення до самогубства спрямоване на примус вчинити самогубство, характеризуеться особливим цинізмом, жорстокістю та підступністю, посягає на невід'ємне право на життя, гуманістичні засади взаемин людей.

Під самогубством традиційно розуміють акт самоусунення. Це поведінка людини, спрямована на умисне позбавлення себе життя, є потуранням цінностей, закріплених в законах, міжнародних актах, через те у багатьох західних країнах самогубство до 1800-го року вважалось злочином, а багато ісламських країн і досі тавруе самогубство як кримінальний злочин.

Перед початком аналізу даного правопорушення доцільно простежити його еволюцію в історичному аспекті та ознайомитись з положеннями радянського кримінального законодавства. Від 1917 р. самогубство і замах на нього були декриміналізовані. Доведення до самогубства залишалось караним, але тільки якщо воно вчинялось шляхом підмови і щодо неповнолітніх або психічно хворих [2]. Термін доведення до самогубства вперше був застосований у 1927 р. Потерпілим визнавалася особа, що перебуває в матеріальній або іншій залежності від суб'екта злочину. Також для кваліфікації за доведенням до самогубства був потрібен непрямий умисел - за наявності у винного прямого умислу на доведення до самогубства вчинене вважалось вбивством [3]. Важливо зазначити, що підбурювання до самогубства і пособництво в самогубстві не були кримінально карними, а такі ж дії стосовно особи, яка через вік або стан психіки не могла усвідомлювати значення своїх дій або керувати ними кваліфікувалося як умисне вбивство або замах на умисне вбивство за умови, що самогубство 
мало місце. Кримінальний кодес 1960 року був найбільш наближеним до сьогодення, включав різноманіття способів доведення до самогубства.

На сьогодні доведення до самогубства або замаху на нього регулюється ст. 120 Закону про кримінальну відповідальність, є не тяжким кримінальним правопорушенням. Родовим об'єктом правопорушення $є$ життя та здоров'я, а безпосереднім - життя людини. Самогубство є різновидом неприродної смерті, при тому доведення до самогубства - єдине правопорушення проти життя, що не охоплюеться поняттям вбивство в законодавстві України.

Перейдемо до розгляду об'єктивної сторони даного правопорушення. В загальному розумінні це поняття охоплюе зовнішній бік діяння і складається 3 діяння, наслідку, причинно-наслідкового зв'язку. Ці елементи обов'язкові. Почнемо розгляд з кінця. Правопорушення про доведення до самогубтва має матеріальний склад, тому наслідок однозначно має бути присутній у вигляді смерті особи або спроби самогубства, яку ще називають замахом, з чим деякі вчені сперечаються, адже замах в агальному розумінні є умисним завданням шкоди іншим, а не собі. В будь якому випадку, правопорушення закінчене за зазначених обставин. Наступним елементом є причинно-наслідковий зв'язок між діянням та наслідком: акт самогубства став наслідком поведінки винного.

Діянням за даним правопорушенням є сукупність дій, спрямованих на доведення іншої особи до самогубства. Спосіб виконання злочинного наміру виступає обов'язковою ознакою об'єктивної сторони. Такими способами є жорстоке поводження, шантаж, систематичне приниження людської гідності та протиправне примушування до дій, що суперечать волі особи, схиляння. До 8 лютого 2018 року їх перелік був обмежений, та вийшла зміна до закону. Відтак з'явилось безпосередньо схиляння до самогубства та інші дії, що визнані оціночними поняттями. Суд на свій розсуд, спираючись на досвід та компетенцію, та аналізуючи обставини конкретної справи приймає рішення стосовно оцінки способу вчненого правопорушення. «Примус до протиправних дій» замінив «систематичний протиправний примус до дій, що суперечать волі особи», що зумовлюе інтенсивніший вплив на свідомість жертви і з більшою вірогідністю змусить її перейти межу, ніж якби негативний вплив був одноразовим. Поняття жорстокого поводження та систематичного приниження гідності, містяться у п. 28 Постанови Пленуму Верховного Суду України № 21 від 7 лютого 2003 р. Під жорстоким поводженням розуміють безжалісні, грубі діяння, які завдають потерпілому фрізичних страждань, болю, психічних переживань, а систематичним приниженням людської гідності є тривале принизливе ставлення [4]. Варто зазначити і шантаж. Це є погроза розголосити правдиві чи помилкові відомості, які потерпілий хотів приховати.

Цікавить поведінка злочинця, як засіб вчинення правопорушення. Серед агресивних реакцій виділяють фізичну агресію або напад - використання фрізичної сили, непряму агресію, агресія, спрямована на іншу особу, і спрямована ні на кого впринципі: крики, биття кулаком по меблях, стінах, дратівливість - готовність до вияву негатив- них почуттів на рівному місці, негативізм - опозиційна манера поведінки від пасивного опору до активної боротьби проти встановлених звичаїв і законів, образу - ненависть до оточуючих за дійсні і вигадані свідчення, підозрілість, вербальну агресію - висловлення негативних емоцій через крики, сварку, словесні відповіді [5].

Однак, як зазначалося вище, 3 розширенням списку способів доведення до самогубства кваліфікуеться як злочинне діяння також і вплив, побудований не на фрізичному примусі, а шляхом схиляння, що часто має підгрунтям довірчі а часом навіть дружні стосунки між потерпілим та правопорушником. Так, останній може умовляти свою жертву, аргументуватуючи гостру необхідність самогубства, накласти на себе руки, пояснювати, що лише у смерті - вихід 3 ситуиції, що склалась, тощо. Така стратегія особливо ефективна 3 психологічно пригніченими індивідами, які ще до початку впливу на них мали думки про самогубство, були незадоволені своїм життям, перебували у стані депресії або апатії. За такого розкладу прояви агресії, негативізму, дратівливості може не бути присутніми в поведінці правопорушника.

Смертельні ігри «Синій кит» та «Червона сова» 3 соцмереж здійснили певний поштовх до включення законодавцем схиляння до способів доведення до самогубства. Ці ігри спрямовували винищувальний вплив на аудиторію з осіб віком переважно від 12 до 16 р., хоча були зафіксовані випадки вчинення самогубств і серед значно молодших дітей. На відміну від дорослих, діти піддаються легшому впливу, для них характерна більша навіюваність, тому вони ставали легкою мішенню для онлайн-злодіїв. До спільнот самогубць долучалися щоб знайти розраду та психологічну підтримку ті, що в такому молодому віці уже зіштовхнулись 3 суворими реаліями: проблеми в школі, вдома, булінг тримали дітей в пригніченому стані, через що вони були готові закінчити життя - це лише полегшувало задачу правопорушників. За допомогою ігор дорослі особи-психологи по той бік екрану поступово руйнували свідомість і психіку жертви, домагались бажаної мети вербальним переконанням, наданням розхитуючих психіку завдань, погрозами вбивства батьків.

Разом з тим зазначається, що законні дії, такі як правомірне звільнення 3 роботи або негативне оцінювання в закладі навчання чи повідомлення нехай принизливих, але цілком справедливих та не висловлених в образливій фрормі відомостей не є способами схиляння до вчинення суїциду. Тому, якщо певна людина під вливом негативних життевих обставин сама наважується накласти на себе руки в силу слабкості харак-

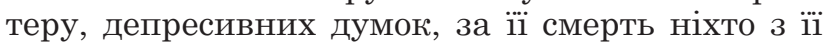
оточення, колег по роботі, знайомих не буде нести відповідальність, навіть якщо, на їі думку, щі особи стали опосередкованою причиною самогубства, бо вони отримали замість неї просування кар'єрною драбиною, мимоволі образили невдалим висловом, вона їм заздрить, тощо.

Описані способи доведення до самогубства загальновизнані, та в законодавствах різних держав е відмінності стосовно їх оцінки. Грузія, Айзербаджан, Росія окремо виділяють по- 
грозу - усний, письмовий, вчинений шляхом конклюдентних дій намір завдати фрізичної чи моральної шкоди. Погрози нагадують шантаж, щоправда 3 розширеним тлумаченням, охоплює і залякування фрізичною розправою потерпілого чи близьких йому людей. Законодавство Айзербайджану відносить погрозу до жорстокого поводження, а Естонія додає до переліку знущання, що також розцінюеться як жорстоке поводження. Республіка Молдова зазначає ще й наклеп, цькування, образу - діяння, які українське законодавство вважає дрібними проявами тиску, не здатними схилити до самогубства за наявності стійкої психіки у особи. Інше бачення способів схилення до самогубства представлені у Литві, Болгарії, Японії, Польщі Білорусі, Аргентині, Данії і інших, які прописали відповідальність за схиляння до самогубства і допомогу вчинення, навіть якщо допомагаючий діяв з високих мотивів, наприклад, релігійних чи гуманних. Іспанія і Сан-Маріно не мають в кримінальному кодексі цього діяння, але представлене вбиство і його види, тож схиляння шляхом вмовляння, примушування, пособництва розгядається як підвид вбивства. За схиляння до невдалої спроби самогубства винний відповідає за тілесні ушкодження. Швеція, Китай, Корея мають схоже бачення: передбачають лише таке діяння як вбивство, i якшо особа вбиває іншу на їі прохання, це діяння вважається кримінально караним [6].

Наступним елементом складу досліджуваного правопорушення є суб'єкт. Ним є фрізична осудна особа, що вчинила правопорушення у віці, з якого, настає кримінальна відповідальність. В даному випадку суб'єкт загальний - 16 р.

Важливим елементом складу є суб'єктивна сторона-ставлення винного до вчиненого та наслідків. Змістом суб'єктивної сторони є вина, як обов'язковий елемент, без якого не настає кримінальна відповідальність, та фракультативні елементи, такі як мотив, наприклад, частими $є$ мотиви з ревнощів чи хуліганські, і мета. Пленум Верховного Суду України в Постанові «Про судову практику в справах про злочини проти життя та здоров'я особи» від 7 лютого 2003 р. № 2 вказав, що під час призначення покарання суди зобов'язані враховувати вид умислу, мотив і мету злочину. [4] Вважається, що суб'єктивна сторона правопорушення за статтею 120 ККУ характеризується виною у формі умислу або необережності. Якщо ж особа не передбачала і не могла передбачити самогубства або замаху на самогубство з боку потерпілого, відповідальність за доведення до самогубства не настає

Через велику кількість суперечок з цього приводу, питання суб'єктивної сторони залишається відкритим. Деякі вчені вважають, що доведення до самогубства вчиняються з будь-якою формою вини. Правопорушник може як усвідомлювати і бажати або байдуже ставитися до настання смерті потерпілого, усвідомлювати і передбачати настання таких наслідків, але сподіватися на їх відвернення, а також не усвідомлювати і не передбачати, хоча повинен і міг передбачити. Опозиційна теорія - теорія умисного правопорушення.

Л.М. Шестопалова відноситься до першої плеяди дослідників. Так, щодо злочинної самовпевненості , винна особа передбачає можливість доведення потерпілого до самогубства або до замаху на самогубство, але розраховуе на конкретні обставини, які здатні, на ії думку, відвернути настання наслідків. Злочинна недбалість характерна тим, що та сама особа не усвідомлює своєї дії або бездіяльності, що утворюе реальну загрозу для цієї людини, не передбачає можливість доведення іншої людини до самогубства або до замаху на самогубство, хоча повинна була за таких обставин і мала змогу передбачити, якщо б винний діяв обачливіше [7].

О. А. Гусак переконує, що доведення до самогубства може бути вчиненне тільки з прямим умислом, оскільки винний усвідомлюе суспільно небезпечний характер своїх дій, передбачає можливість і неминучість настання наслідків у вигляді самогубства потерпілого, бажає їх настання [3]. Вчена також указуе на важливість характеру взаємин потерпілого та винного, інформованість останнього про індивідуальні риси характеру потерпілого, 3 огляду на які винний обирає спосіб найбільш результативний для того, щоб потерпілий зробив вибір на користь позбавлення себе життя.

На мою думку, даний злочин може бути тільки умисним, проте цей умисел не обов'язково має бути прямим. При прямому умислі винний розуміє, що скоюе діяння, наслідком якого є смерть, а при непрямому - може передбачати наслідки та бути до них байдужим. Так, винний щодня, різноманітними способами, поєднаними 3 dpiзичним і психологічним влпливом пригнічуе потерпілого, не бажаючи йому смерті напряму, хоча і розуміе, що такі дії можуть призвести до самогубства останнього, психіка якого хитка, i може не витримати. Та винному байдуже чи самогубство зрештою відбудеться - життя цієї людини не має цінності для правопорушника. Маємо поєднання із прямого умислу стосовно образ і непрямого- щодо наслідків. А от включення необережної форми вини до суб'єктивної сторони доведення до самогубства може призвести до того, що необережно сказане слово, невдалий жарт, у результаті яких потерпілий прийняв рішення покінчити із собою розцінюватиметься як правопорушення проти життя людини.

Мотив - фракультативна, але важлива ознака. Часто це побутові сварки. У Герцаївському районному суді Чернівецької області 3 березня 2018 року розглядалась справа про приниження і побої пасинка вітчимом, в результаті чого малолітній вчинив спробу повішання, але був витягнутий вчасно з петлі. Вітчима судили за доведення до замаху на самогубство стосовно неповнолітнього - ч. 3 ст. 120 ККУ [8]. Дійсно, потерпілими часто виступають неповнолітні через негаразди в сім'ї. Взагалі, мотиви вчинення такого правопорушення можуть бути різними та не мають значення для кваліфікації в сучасній редакції. Він може враховуватись для призначення покарання.

Варто зазначити обтяжуючі обставини, якими є вчинення злочину щодо особи, що перебувала в залежності від особи виного, стосовно двох чи більше осіб, а особливо кваліфрікуючою - щодо неповнолітнього. Так, залежність розглядають в аспекті, передусім, залежності матеріальної, що виражаеться в отриманні потерпілому їжї, притулку, грошей від свого кривдника, при тому 
самостійно цих благ він набути не міг через стан здоров'я, вік, тощо. 3 огляду на щю обставину дії 3 доведення до самогубства особи, яка не може уникнути спілкування з правопорушником, з метою врятування своєї психіки $i$, як результат, життя від його руйнівного впливу, розцінюються як особливо жорстокі, і цинічні. Особами, що виконують роль утримувчів часто виступають батьки, один 3 подружжя, опікуни. 3 морального аспекту це ще більше погіршує стан речей, якщо ці особи стосовно своїх близьких вчиняють дії $з$ метою доведення їх до самогубства. Також видялють службову залежність, в силу підпорядкованості на роботі. Вона грунтуеться на страху звільнення, пониження в посаді, несплати премії. Небезпека цього виду залежності природньо полягає в тому, що потерпілий не може триматись поодаль від особи, що руйнуе його психіку, бо звільнившись 3 роботи, втратить дохід і ризикує опинитись без засобів для існування, що добре усвідомлює винний і використовує це на свою користь. Третій вид залежності не конкретизовний і має назву іншої залежності, виникає у разі якщо потерплілий відчуває себе зобов'язаним чи підкореним особі правопорушника за якісь його дії в минулому, наприклад, винний раніше врятував його життя чи життя його дитини. Залежність пов'язуеться з родинними, партійними, релігійними, та іншими відносинами [4].

Законодавець, конструюючи кримінально-правову норму, що міститься у статті 120 КК України, передбачив наявність спеціального суб'єкта - особу, від якої потерпілий перебуває в матеріальній, службовій чи іншій залежності, службову особу, яка користуеться своїм становищем. Доведення до самогубства декількох осіб потребуе посиленої відповідальності через підвищену суспільну небезпечність, особливо, якщо поєднане 3 діяльністю сект, носить масовий характер, як і доведення до самогубства неповнолітнього.

Законодавства таких країн, як Росія, Айзербайджан і Молдова не відносить до кваліфрікуючих обставин службову залежність, а Грузія і Естонія не згадують матеріальну, що є значиним недоліком. При тому Молдова зазначає, що якщо в матеріальній залежності особа перебувала від батьків, близьких родичів, чи іншого 3 пдружжя і така особа схилила потерпілого до самогубства, ця обставина ще більше обтяжує діння [6].

Вчені розробляють пропозищії щодо доповнення списку обтяжуючих ознак. Одна з них - включення корисливого мотиву, бо діяння вчиняеться тоді із прямим умислом, винний усвідомлюе, що у разі самогубства потерпілого він отримає можливість привласнити його гроші чи інше майно або зможе позбутися матеріальної залежності від потерпілого, який виступає його кредитором за цивільно-праавовим домовленостями [3, с. 17].

Окрім цього, доцільно доповнити статтю 120 КК України в аспекті спеціального виду звільнення від кримінальної відповідальності за умови що особа добровільно припинила свої протиправні дії, відшкодувала шкоду, звернулась до правоохоронного органу та допомогла розслідувати правопорушення та усунути негативні наслідки їі дій. Механізм звільнення від кримінальної відповідальності зможе заохочити особу винного до припинення протиправних дій і відшкодування шкоди, та врятує не одне життя.

Висновки і пропозиції. Підсумовуючи зазначимо, що склад правопорушення зазнав змін з першої редакції 1917 року і наразі знаходиться в стадії трансформування, що важливо для ефрективного подолання проблеми доведення до самогубства в сучасних умовах і з втручанням сощіальних мереж в приватне життя людини. Дана норма потребує додавання корисливого умислу як обтяжуючого елемента та врегулювання питання доведення до самогубства завдяки мережі Інтернет, а також додаванням норми, яка звільняе від відповідальності за дане діяння, за сукупності певних умов.

На сьогодні родовим об'єктом даного складу правопорушенння є життя та здоров'я, безпосереднім - життя людини. Доведення до самогубства є діянням, що утворюе об'єктивну сторону у спосіб жорстокого поводження, шантажу, систематичного приниження, протиправного примусу до дій, що суперечать волі особи, шляхом схиляння. Суб'єктом передбаченого в ч. 1 ст. 120 КК правопорушення може бути осудна особа, яка досягла 16-річного віку. Питання щодо суб'єктивної сторони залишається невизначеним. Деякі дослідники визначають, що суб'єктивна сторона діяння, передбаченого статтею 120 ККУ характеризуеться виною, яка може бути як у фрормі умислу, так і у формі необережності, а деякі наполягають на наявності лише умисної вини у формі прямого умислу. На мою думку, правопорушення за статтею 120 ККУ може бути вчинене тільки умисно, однак форма вини може виражатися як у прямому, так і в непрямому умислі. Кваліфрікуючими ознаками правопорушення, передбаченого статтею 120 ККУ е вчинення його щодо особи, яка перебувала в матеріальній, службовій іншій залежності, двох або більше осіб а особливо кваліфрікуючою ознакою - щодо неповнолітнього.

\section{Список літератури:}

1. Войцек В.Ф. Клиническая Суицидология. Москва : Миклош, 2007. 280 с.

2. Уголовный кодекс УССР, утвержденный ВУЦИК 23 августа 1922 г. (с измен. и дополнениями по 1-ое июня 1924 года и с алфав. указ.). [6-е офиц. изд.]. Харьков : Юрид. изд-во Наркомюста УССР, 1924. $104 \mathrm{c}$.

3. Гусак О. А. Кримінально-правова характеристика доведення до самогубства : автореф. дис. ... канд. юрид. наук : 12.00 .08 : Кримінальне право та кримінологія; кримінально-виконавче право. Нац. ун.-т Одеська юридична академія. Одеса, 2014. С. 9.

4. Постанова Пленуму Верховного Суду України № 2 від 7 лютого 2003 р. - Про судову практику в справах про злочини проти життя та здоров'я особи. URL: http://zakon0.rada.gov.ua/laws

5. Ениколопов С. Н. Некоторые результаты исследования агрессии. Личность преступника как объект психологического исследования. Москва : Всесоюзный ин-т по изучению причин и разработке мер предупреждения преступности, 1979. С. 100-109.

6. Колінько О.О. Доведення до самогубства: порівняльна характеристика Українського і зарубіжного кримінального законодавства : зб. наук. пр. 2010. С. 258-263. 
7. Шестопалова Л.М. Самогубство та доведення до самогубства: заходи протидії : автореф. дис. ... канд. юрид. наук : спец. 12.00 .08 «Кримінальне право і кримінологія; кримінально-виконавче право». Нац. академія внутр. справ України. Київ, 2001. С. 11.

8. Вирок Герцаївського районного суду Чернівецької області від 3 березня 2018 року Єдиний державний реєстр судових рішень. URL: http://reyestr.court.gov.ua/Review/72576682 (дата звернення: 20.03.2021).

\section{References:}

1. Vojceh V.F. (2007) Klinicheskaja suicidologija. Moscow: Miklosh, 280 p.

2. Ugolovnyj kodeks USSR, utverzhdennyj VUCIK 23 avgusta 1922 g. (s izmen. i dopolnenijami po 1-oe ijunja 1924 goda i s alfav. ukaz.). [6-e ofic. izd.]. Kharkiv: Jurid. izd-vo Narkomjusta USSR, 1924. 104 p.

3. Gusak O.A. (2014) Kryminal'no-pravova harakterystyka dovedennja do samogubstva: avtoref. dys. ... kand. juryd. nauk: 12.00.08: Kryminal'ne pravo ta kryminologija; kryminal'no-vykonavche parvo. Nac. un.-t Odes'ka jurydychna akademija. Odesa, 9 p.

4. Postanova Plenumu Verhovnogo Sudu Ukrai'ny No 2 vid 07 ljutogo 2003 r. - Pro sudovu praktyku v spravah pro zlochyny proty zhyttja ta zdorov'ja osoby. URL: http://zakon0.rada.gov.ua/laws

5. Enikolopov S.N. (1979) Some results of the study of aggression. Personality of the criminal as an object of psychological research. Moscow: All-Union Institute for the Study of the Causes and Development of Crime Prevention Measures, pp. 100-109.

6. Kolinko O.O. (2010) Driving to suicide: the characteristic of the Ukrainian and foreign criminal legislation is trivial: zb. sciences. pr., pp. 258-263.

7. Shestopalova L.M. (2001) Samogubstvo ta dovedennja do samogubstva: zahodi protidiï: avtoref. dis. ... kand. jurid. nauk: 12.00.08: Kriminal'ne pravo ta kriminologija; kriminal'no-vikonavche parvo. Nacional'na akademija vnutrishnih sprav Ukrainy. Kyiv.

8. Virok of the Hertsaivskyi district court of the Chernivtsi region from 3 March 2018 to the United State Register of Court Decisions. URL: http://reyestr.court.gov.ua/Review/72576682 (accessed 20 March 2021). 